\title{
An Allegation against Gulen Movement and its Founder in Azerbaijan
}

\author{
Birol Topuz \\ PhD Candidate, Qafqaz University, Azerbaijan \\ btopuz@qu.edu.az
}

Doi:10.5901/ajis.2013.v2n2p11

\begin{abstract}
There are several ways to be popular or mediatic in this age. One of the ways of this is to select a popular figure from society, and to write something against him/her. It is seen a sample of this attempt in Azerbaijan as it is done many other places. The author, Fuad Aliyev, selected one of the popular figures, Fethullah Gulen, for him to be known by the society. His paper about Gulen movement in Azerbaijan is an argument against the action figure and the founder, and against the reality of the movement. It exactly ignores its purpose, and to be found nothing good in it. The picture is distorted and the features that draw it are almost exclusively negative. The article presents the founder of Movement as an opportunist and pragmatic intolerant. Consider the work as an example of religious fundamentalism. He describes it as a phenomenon of the traditional bourgeoisie, said that his members are the most ignorant, least sophisticated of the emerging middle class, for whom membership of the work is a symbol of social mobility. The author does not merely have some conversations, but uses short anecdotes to illustrate his personal views. Often, we pass a critical opinion about a witness to the global and absolute disqualification of the institution by the author. Varieties of the resources, also, say that it is so difficult to accept as an academic paper. The apparent form with which the paper presents a sociological study dispassionate and objective, from a statement fails to conceal its reality: a frontal allegation against the movement, from a certain ideological premises. These premises set forth in this occasion and previous ones by the author can be highlighted: the exaltation of a new morality, the rejection of the institutional succeses, the critique of movement's belief and social order, denial of the religious sense of obedience, and appreciation of doctrinal fidelity as opposed to freedom of conscience, and so on. This paper will illusturate the realities of the movement in Azerbaijan, and its importance for Azerbaijan's development since 1991. Additionally, famous people of the society, sociologists, politicians, pedegogues' views will be shared.
\end{abstract}

Keywords - Gulen, Movement, defamation

\section{Introduction}

Sociology is neither a dogma nor power. It is a social science which critiques, observes, explicites the human being behaviours as an intellectual activity (Bourdieu,1997). It is accepted by the whole psychologists that people would like to be known. It is a characteristic reality of all human beings. There are several ways to be popular or mediatic in this age in the academic world. One of the ways of this is to pick a popular figure from the society as a opponent, and to write something against him/her. It is seen a sample of this effort in Azerbaijan in this years as it is done many other places before. The researcher, Fuad Aliyev, selected one of the popular figures, Fethullah Gulen, for himself to reach at his "characteristic" goal. His paper about "Gulen movement in Azerbaijan" is an argument against the action figure and the founder, and against the reality of the movement. It exactly ignores its purpose, and to be found nothing good in his work about movement and its founder.

It is certain that trying to analyze social and religious issues as an objective manner without a sided view perspective and prejudice, and to be neutral against the issues are truly difficult with researchers' religious experience backgrounds (Wach, 1995). The picture is distorted and the features that draw it are almost exclusively negative. The neutrality is the first and basic principle of all social science works in terms of the science ethics. Unfortunately, objectivity is lost in this paper. It can be seen easily after having a deep view the whole paper.

The work presents the founder of Movement as an opportunist and pragmatic intolerant. It believes the movement as an example of religious fundamentalism. The author describes it as a phenomenon of the traditional bourgeoisie, said that his members are the most ignorant, least sophisticated of the emerging high class, for whom membership of the work is a symbol of social mobility.

All social or religious phenomenon could be evaluated with this perspective. From this view, sociology or religious sociology is science which tries to understand the events happening in the society (Yıldırım,2003) The writer does not merely have some conversations, but uses short anecdotes to illustrate his personal views. Often, we pass a critical 
opinion about a witness to the global and absolute disqualification of the institution by the author. Varieties of the resources, also, say that it is so difficult to accept as an academic paper. Types of the resources will be analyzed in details to illustrate what meant above.

This paper will illustrate the realities of the movement in Azerbaijan objectively, and its significance for Azerbaijan's development since 1991. By doing that famous people of the society, sociologists, politicians, pedagogues' and members of the movement views will be shared.

\section{Why was this article written? Why the defamation is selected as a main theme?}

As it is stated in the first section, choosing a popular figure to be famous in the academic life is too common attitute. It is a common and the simplest way to start your career strongly at the first step. Many of the unknown people in academic world like Fuad Aliyev did the same things in the past. Gulen is tried to be portrayed in a different ways to the public such as a CIA/Zionist agent, a US puppet, a secret cardinal of the Pope and a Western Trojan horse in the Muslim world who is trying to either Christianize Muslims or making it easy for Western powers to exploit the Muslim world through his moderate Islamic teachings; on the other hand, he is displayed as anti-Semitic, anti-Western and trying to Islamize Christians, and as a second Khomeini who is trying to establish an Islamic caliphate in the world (Türker, 2009).

Even if, there are exceptions, in the some works, in brief, Gulen is displayed as an Islamic danger to the Western world who is trying to establish an Islamic caliphate by helping of religiously-sanctioned dissimulation as his main strategy. Most of these articles in this grouping argue that while Gulen is promoting tolerance, understanding, and interfaith dialogue, in reality, he is establishing his caliphate secretly.

As it is stated in Dogan Koc's paper (2012), one of the initial defamatory papers was written by Paul Stenhouse at Quadrant. On the founding of the Fethullah Gülen Chair of Islamic Studies and Interfaith Dialogue, within the Centre of Inter-Religious Dialogue at the Fitzroy campus of the Australian Catholic University in Melbourne, Stenhouse (2007) raised questions about Gulen, and implied that the Gulen Movement is a 'group that is ex professor dedicated to promoting an Islamist ideology.' As can it be understood clearly from his title of the article, "Islam's Trojan Horse? Turkish Nationalism and the Nakshibendi Sufi Order," he emphasizes that in spite of the fact that the Gulen Movement is promoting tolerance and interfaith dialogue, in reality it has a hidden Islamist agenda.

Another claim about both movement and its founder is that Gulen has a hidden agenda and uses moderate Islam as a mask very often refer to a doctored video recording of Gulen. These articles claim that Gulen justifies this disguise by religiously-sanctioned dissimulation, and is secretly infiltrating Western society (Fitzgerald, 2008; Rubin, 2008; SharonKrespin, 2009; Stenhouse, 2007; Mitzell, The Rise of a New Ottoman Empire: The Trap of Interfaith Dialogue, 2008). These articles also commonly refer to the Gulen Movement as a "secret cult" rather than a social movement.

Another argue was done by Michael Rub such as Gulen eventually will establish an Islamic state in Turkey, just like Khomeini did in Iran (2008). In a different article, Rubin (2010) changes his claims and defines Gulen as "a cult leader, and the closest thing Turkey has to Khomeini-in-exile." As it is seen that there are many papers about movement, unfortunately, nearly all of them describes it in a different way or use so different terms to name the group. Fitzgerald (2008) also has the same ideas with Rubin. Many other authors who are doing the same work systematically can be outlined such as Sharon-Krespin (2009), Aland.

\section{The way of criticing of an article}

First of all, it should be mentioned that Mike Metcalfe's work named "Eleven ways to critique an article" helped me during setting up my framework. In this work it is attempted to use an old, yet usefull questions, "What is his argument in this paper?" and "Is author's conclusion justified?", as a critiquing method using perspectives such as systems thinking, evolution theory, picturing, dialectic and the perspectival thinking. Because it is know by all academicians that good critiquing requires insight, asking thoughtful questions and seeing behind the text.

At the beginning it should be underlined that skeleton of article is not clear. What is the aim of the article? What is his hypothesis about the movement? What method/s will be used to analyze author's hypothesis? Which group is chosen as an experimental group? Or is it based in theory rather than experiment or based in experiment rather than theory? And so on...

C. West Churchman's suggests that new data can also come from finding new perspectives, which can give you more choices. For that the following questions were analyzed to reach at a certain and scientific outcome: 
- What is the explicit or implicit argument of the paper? Was it stated upfront?

- What evidence is brought to support the argument?

- Was this evidence convincing, novel, insightful?

- Were there any observations?

- Who is the intended audience?

- Is the paper explicitly persuasive to this audience?

- What did you learn new from the article?

- What purpose has the author had in writing the article?

- What were the inputs to the article?

- What data (empirical and previous literature) was the article founded upon?

- Does the article process these inputs well?

- Are the outputs of the article, the conclusion and recommendations fully justified?

- Does the author display observation or measurement skills greater than a lay person or common sense?

- Are the observations intended to provide objective knowledge or merely to assist thinking?

- Are the authors seeking the one truth or do they acknowledge alternative interpretations of the observations?

- Do the observations produce convincing, objective knowledge?

- Are the observations repeatable?

- Are the observations all the evidence that is provided towards the conclusion?

- Is there any acknowledgement that observations are 'theory laden'?

Linstone, [1984, 1993, 1999] sometimes with Mitroff [1993], has recommended that not simple social situations require to be critiqued from three views, a technical $(T)$, organisational $(O)$ and personal $(P)$ perspective. For analysing, it means that it can be reflected on which perspective the article has been written from, and how it would be different if written from another perspective.

- Is the article about people, organisations or things?

- Have the different perspectives of the people and/or cultures being provided?

- Have the people or cultural norms been treated as 'things?' or as intelligent and experienced people who can inform the author?

Another way of critiquing is Linstone's [1999] various perspectives concepts and Haynes' [2000] Perspectival Thinking. The fundamental theory of knowledge is that it is practical to categorize two types of knowledge.

There shows to be some very different understandings about the role of observation (including sound, touch, smell and taste) in the study. Reasoning and thought experiments are measured sufficient to generate practical knowledge. Measurement problems, the lack of dependability of the human senses and a lack of explanation of why the study occurred contributes to this attitude.

This is short of focus of observation to study can also be found in some areas of science. How the author perceives or uses observation provides a perspective with which to critique an article.

\section{Analyzing of some data from the article:}

To check the academic quality of the work, some of the quotations were choosen below:

1) In Azerbaijan, the Gülen movement has succeeded in reaching out to a diverse population, but especially to urban elites.

What is the scientific evidence of this claim/argument? Who calculated the number of the movement members in Azerbaijan with what sort of serach/survey?

2) It is different from other Islamic movements in that it promotes its religious teachings not through outright proselytization, but discreetly through its network of secular educational institutions, social media and business associations.

Islamic movement? To describe the group with these terms, some academic and scientific data accepted by both the members of the movement and others should be proved.

3) Because of the Hizmet movement's political quietism and its appearance of secularism, Sunni Islamists have repeatedly criticized it as "un-Islamic," for introducing "innovations" (bida) into Islam, and for ignoring the problems that religious Muslims face. 
Sunni Islamists? Who are those? Where did they critique the movement in which way? All of these questions cannot be replied in this "Academic work" unfortunately. It can be say that there is a "Scientific Quietism" in this paper.

4) Alternatively, both Azeri secularists and Shia religious activists have accused the Gülen network of promoting a hidden Turkish-Sunni Islamist political agenda, of serving as political agents for Turkey, and of promoting Sunnism against Azerbaijan's native Shiism.

Again the same problem is here. Who are those Azeri secularists and Shia religious activists? Where did they accuse the movement with what sort of activity? With conferences, seminers, TV programs, speeches, academic works, published books or with just gossips or untrue defamation knowledge?

5) Nursi's followers formed themselves into a hierarchical organization that resembled the structure of a traditional Sufi order and soon became popularly known as the "Nurcu Movement."

Where is the proof of this quotation? Empirical data, literature or evidences?

6) In 1950, the Turkish Grand National Assembly passed a resolution to rehabilitate the literary heritage of Said Nursi, and this thereby effectively legalized the publication and translation of his works and the movement they inspired.

All paper tries to show the movement or "Nur movement" as a dangerous formation. On the other hand, this quotation denies all data given rest of the paper. Since, in other parts of the data, it is stated that both movements have problems with the government.

7) Through its business connections, the movement has accumulated enormous financial resources that it uses to support its social activities and public outreach in Turkey and elsewhere around the world.

This resurce belong to Ahmet Şı. For get more details about him and his relationships with the movement, Dogan Koc's paper about defamation about Gulen should be read. Then, Ahmet Şık's evidences could be reviewed objectively. All data can be used in academic works without analyzing in details.

8) One analysis that drew from Turkish media resources showed that the Hizmet movement experienced a sharp increase in its total operating capital beginning in the mid-1980s: today, the movement's total worth is estimated to be more than $\$ 50$ billion and to comprise about 30 percent of the Turkish economy. Who calculated this amount with concrete figures is not clear. It only seems a speculation or gosip, not empiric and certain data depends on statistical knowledge or researches.

9) Moreover, according to the High Command of the Armed Forces of Turkey, the number of Gülen's followers reaches as high as 4 million people in Turkey. This knowledge depends on only unknown website data, magazine knowledge. There is not a concrete population research about this. As it is known that speculations can be used as an academic evidence.

10) In Turkey, the Gülen movement, as with some other Nurcu movements, is a well-structured, hierarchical organization. Thus, a typical Turkish city-level cell usually consists of the following levels: shagirdlar (students), uy imams (groups of five students and their leaders), semt imams (an association of fives on the basis of the urban district or educational institution and their leaders), and bolge imams(head of district level.)

11) It again depends on unreadable website resource; there is no certain knowledge about the organizational structure stated above in any other resources.

12) Students are recruited and controlled at a local level by Nurcu abis (brothers) and by ablas (sisters). According to former members of this network, the movement possesses its own security service that is tasked with rooting out moles and agents of national intelligence and law enforcement services.

If the movement is accepted as an "Organisation" of course some postions could be normal logically. Why they were trying to be shown dangerous then?

13) The movement keeps a database of all its members, and the training of each new recruit emphasizes the need to exercise discretion in revealing their involvement with the Gülen network. Students are additionally instructed to respect and obey the network's leadership.

Another claim is that without certain evidence.

14) After the collapse of the Soviet Union, the movement began to focus its international religious outreach and networking efforts in the newly formed republics of the Commonwealth of Independent States (CIS) and among the Muslim populations located in the Russian Federation.

"Religious outreach", there is not any proof that Gulen movement is doing religious works not only in CIS but also any other place in the world. For the reason that, as it is stated in that paper as well, movement is mostly 
openning educational institutions.

15) After winning Aliyev's support, the Gülen movement enjoyed real opportunities to expand its activities, and by 1993, the movement had actively begun building a network of educational institutions and businesses.

As it is stated here, President Aliyev supported the movement during all of his life. The author implys that President Aliyev could not understand this movement's aim or hidden agande with all of governmental power in his hand such as intelligent service, police department and so on, however, I recognized the dangerous with few website gossips.

16) ...the Support to Youth Foundation is relatively more "religious" because besides its charity work and the courses it offers in English, computers and other subjects for children, it holds Arabic and Qur'an recitation courses, has a library full of Islamic religious books, ...

What is the academic proof of all of these claims?

17) The network in any given country is usually divided into three tiers or groups. The first group includes people who are closest to Gülen and the immediate circle of his most trusted and loyal followers. The second group includes those who work directly for the movement to achieve its larger objectives. The third group includes mainly sympathizers of the movement and they largely consist of journalists, business people, public officials, alumni of Hizmet schools, and friends. While this third grouping is not always formally a part of the network, the network does often mobilize it to pursue various ends.

Who divided the group in three parts? When did it happen? What is the structural framework of this? What is the evidence of this claim academicly? All of those are not clear.

18) Many worry that the AKP's success in Turkey, which has clearly been buttressed by the Turkish Nurcular and Gülen movements, could also inspire the movement's Azerbaijan-based adherents.

Who are those "many"? Which survey revealed this reality in Azerbaijan? When was it done?

19) The movement's members hardly display their religious agenda in public at all. There is, for example, no Religious Studies Department at Qafqaz University anymore; there isn't even a prayer room. In other Gülenaffiliated institutions, there are no official religious ceremonies or events.

This info conflicts with all of rest of the paper itself.

These were only a few samples quoted from the paper. The number of the sentences could be increased easily. However, it is believed that these samples are quite enough to display what is meant indeed with these samples?

In fact, the author is not conducting a research, he is collecting mainly previous news, and nonacademic publications without focusing they are true or false. This should be underlined at first. To recognize it, this question can be asked: What sorts of sources are used in the paper? When we look at directly to resources it will be seen that most of the resources are TV news, TV programs, and newspapers. It means that sources are nonacademic, in a different way, noncritical ones.

The author used a few academic resources as well. Unfortunately, those are used quite differently. When we have analyzed the paper, mainly four or five different people's sources are used in all work is seen. As it is stated above, those works published misaimed about Gulen/Movement.

\section{Resource analyzing of the article}

1) Davidov, M.N. "The Activities of Turkish Religious Sect Nucular" Деятельность турецкой религиозной секты «Нурджулар»." (Russian, blog.), November 3, 2007. The Institute of the Near East http://www.iimes.ru/rus/stat/2007/03-11-07b.html

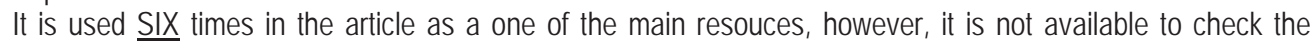
information stated in the paper.

2) Ahmet Sık "İmamın Ordusu" ("The Army of Imam" in Turkish), http://xeberler.files.wordpress.com /2011/04/51984426- dokunan-yanar.pdf. Accessed in July 2012 -

His book was collected by the court due to containing false information about Gulen and movement. Since, his book contains nearly all untrue information about them, thus it was collected by court decision from the society. It is used TWO times.

3) Jeyhun Alekperov. "The Turkish Gambit" and the view from over the ocean. Турецкий гамбит» и взгляд из-за океана" (Russian) The First News Azerbaijan, June 20, 2012,http://1news.az/authors /130/20120620030903621.html\#page999. 
It was TWO times used. It is written in Russian language, thus, it is not possible to analysis to correction of knowledge stated here.

4) Turan 2009

It is not acceptable as an academic resource in this style. Is it a book or article or something else? There is no a link to see what is given there.It was used THREE times.

5) Arif Yunus Islamic Palette in Azerbaijan, Adiloglu, Baku 2012. Is it a book or article?

There is an ambiguity in this resource to control it; unfortunately it is used SIX times in the work as one of main resources.

6) Balci Bayram is used four times in all paper with sometimes unclear resources such as Balci, 2008?

7) Goksel, Nigar "Religiously-Inspired Bonding: Changing Soft Power Elements in Turkey's Relations with Azerbaijan," Vol. 4 N. 8, 2011,

It was used TWO times

8) Eldar Mamedov, "Azerbaijan: Evaluating Baku's Attitude toward the Gülen Movement," February 16, 2012 Eurasia.net,

It was used SEVEN times

As it is seen here clearly, EIGHT (8) different resurces were used in different places THIRTHY TWO (32) times. Most of these resources are, unfortunately, controversial. To claim something good or bad is difficult with these resources academically. If it is done, it is clear being recognized as a defamation effort.

\section{Catagories of resources used in the paper :}

\begin{tabular}{|lc}
\hline Types of the resource & Number \\
\hline Journal Article & 3 \\
\hline Book & 1 \\
\hline Newspaper & 5 \\
\hline Website & 20 \\
\hline Blog & 2 \\
\hline TOTAL & 31 \\
\hline
\end{tabular}

Seeing that it is noticed that nearly only $10 \%$ percent of the resources can be accepted as "Academic Resource" of the work. Blogs, newpapers, unknown magazine resources are not admitted as an academic resource. The real term of those can be named as "Gossip" in academic world.

It is known by all academicians that the numbers of the resources are not significant for the academic works. The quality of the resources becomes more important than its data number. The quality of the data could be seen only by the numbers of academic journals, books, magazines and then others.

Another matter is ambiguity of some basic terms such as anti-Semitism, anti-American, antivatican, type of movement. These are all not clear. The paper tries to draw a picture about movement as a devil to scare people who deal with this movement.

The certain discribtion of the movement is not clear as well. Is it accepted as a cult, sect, NGO or denomination? In some places of the paper group is described as "Islamic movement", "educational organization", "Government supported organization" for nationalism aims. Another conflict is comparison of the movement with Alevis. Alevis are exactly diffenret from Gulen movement.

The Hudson Institute published the paper introduced itself with the following words:

"Hudson Institute is a nonpartisan, independent policy research organization dedicated to innovative research and analysis that promotes global security, prosperity, and freedom".

This identification is too meaningfull and significant for the reputation (fame) of the institution that "independent policy research organization". It means that they will only be deal with objective, important, and nan-partizan issues by helping of scientific outcomes. In other words, they will publish only the papers trusted fully. It is difficult to believe that everybody could be published their papers there without any editions. Since, all journals have a group of people working as reviewers and editors. It is certain that Hudson Institution's journal also has the same staff doing the same thing like others do. If it is, there is key question need to be asked here: Why did they let Mr. Aliyev publish his paper in their journal 
with all of these misused, unbiased data? There are only two possible answers here. First one is that editors did not deeply analyze the work. The second one is worse than the first choice that they were using their journal for defaming Gulen Movement, thus, they published Fuad's paper there as an academic paper. Maybe, Fuad was guided by those who are making preparation to weak Islamic society like Gulen movement. From this view, this paper is not making guilty only Fuad Aliyev but also the journal.

To learn more about the academicians', journalists, and politicians view please see the following papers:

1) The Gulen Inspired Turkish Schools in Baku, Azerbaijan, and Mystery of Their Successes, via http://www.internationalconference.com.my/proceeding/icm2011_proceeding/084_316_ICM2011_PG1182_11 91_TURKISH_SCHOOLS.pdf

2) The historical development of the Azeri education system and the effects of the private Azerbaijani-Turkish schools on the system via http://www.mcser.org/images/stories/JESR-Special-Issues/JESRDecember2011/birol-topuz.pdf

3) Quality movement in Azerbaijan schools: Gulen-inspired Turkish Schools Experience via http://journal.qu.edu.az/content.php?page=article\&j_id=1059\&s_id=105\&a_id=797

4) The Role of the Private Universities in Globalization Process: Case Study of Azerbaijan, via http://abwic.org/Proceedings/2011/Proceedings-2011.pdf, and http://www.au.edu.az/uploads/disk_02.12.2011/konfranslar/Qloballasma\%20s\%3Fraitind\%3F\%20davaml\%3F \%20inkisaf\%3Fn\%20aktual\%20probleml\%3Fri.\%20Beyn\%3Flxalq\%20konfrans\%3Fn\%20materiallar\%3F..pdf

\section{Conclusion}

If a sociologist have an understanding of ontological perspectives of religious relationships' practical reflections and follow his work by having this concious in his mind while analyzing it, the possibility of having objective outcomes increase. Sometimes, a social scientiest lives a dilemma himself. From a view, he also has a belief about a person, group or religion. On the other hand, he has to use the method of sosciological objectivity in every case (Yıldırım,2003).

The paper named "The Gulen Movement in Azerbaijan" is an argument against the movement and its founder and against the reality of the movement fully. Close the eyes to its purpose, found nothing good in it. The picture is distorted and the features that draw it are almost exclusively negative.

It presents the founder of Gulen Movement as an opportunist and pragmatic intolerant. The author displays it as a phenomenon of the traditional/religious bourgeoisie, and said that group members are the most ignorant, least sophisticated of the emerging high class, for whom membership of the movement is a symbol of social mobility. Gulen Movement members are made of the work in its view by a certain gloomy charm to be part of something else, "hidden agenda".

The author's purpose is, as he confesses, having conversations in public with one girl who left Gulen Movement in accordance with "Musavaat Newspaper". In fact, respondent is much less frequently, and with statements that sometimes contradict the general thesis of the article. Moreover, the author does not merely have some different types of surveys, but uses short, nonacademic anecdotes to demonstrate his personal views.

The clear form with which the article presents a sociological study dispassionate and objective, from a statement fails to conceal its reality: a frontal allegation against the movement, from a certain ideological hypothesis. These premises set forth in this occasion and previous ones by the author can be highlighted: the exaltation of a new morality, the rejection of the successes of the educational institutions, the critique of religious side of the movement, denial of the cultural/traditional sense of obedience, and appreciation of doctrinal loyalty as opposed to freedom of conscience in the structure of the movement.

Author's starting point is the supposition of a extensive animus against Gulen Movement. He claims that he has not done more to confirm the obvious: a negative agreement already exists among authorities of the phenomenon with the sample of President Aliyev's view. In fact, the views are too positive and many other academicians' works honor to the work of Gulen Movement in Azerbaijan since 1991, many experts and people, well-known personalities of the cultural, political, economic have all positive vews about it. And thousands of people from all various backgrounds who do not belong to Gulen Movement published in the international press.

All the facts mentioned in the article available all to want to know, and perfectly testable. Anyone can learn and report on Gulen Movement regardless of the degree of relationship with the movement. All it takes is a sincere wish to reach the reality, unbiased, and seeing the wealth of literature and, above all, real life and real people and institutions that 
represent or are the reality of the work. Reliability to the movement not to be necessarily present in the mind of reporting, but in the reality of reporting, since the history of Gulen Movement is above all a history of faithfulness to the charism of their Founder has, and many thousands who have joined their lives freely into the Gulen Movement.

The author of the article is not a historian or movement member. Thus, his offering is not exactly as we have known or seen. Unfortunately, it is clearly seen that the article does not contain the scientific rigor or critical apparatus, documentary, statistical. It is also not accepted as an ordinary sociological study. Nearly all parts of the paper are a hybrid of personal narrative, cultural reflections and untrue resources about Gulen movement.

In addition to the absence of documentary sources and critical apparatus, the suspected scientific nature of the article is compromised by the serious charges often containing contradictory without assurance scientifical sincerity. The study examines the reality of Gulen movement in Azerbaijan from a perspective far removed from the understanding of its purpose, structure, internal relationships, faith and the historical accuracy.

\section{References}

Aliyev F. (2013), The Gülen Movement in Azerbaijan, Journal of Current Trends in Islamic Ideology, Vol. 14, Hudson Institute Publication.

BOURDIEU, Pierre, 'Toplumbilim Sorunları', Kesit Publishing,1997, İstanbul. Book.

Churchman C.W. (1979), The Systems Approach and Its Enemies, Basic Books

Eemeren, van F.H., Grootendorst, R. and Kruiger, T., (1987), Handbook of Argumentation Theory, Dordrecht: Foris Publications.

Fitzgerald, H. 2008. Jihadwatch. Retrieved Feb 5, 2013, from http://jhadwatch.com

Haynes J, 2000, Perspectival Thinking, NZ: OneBook and Company

Koc D.[2012], Strategic Defamation of Fethullah Gülen: English vs. Turkish,

Universial Press of America

Linstone, H. (1984) Multiple Perspectives for Decision Making: Bridging the Gap between Analysis and Action, Elsevier Science Pub Co, NY.

Linstone H A. [1999] Decision Making for Technology Executives : Using Multiple Perspectives, Artech House Publishing: Boston

Mitroff, Metcalfe and Linstone H, The Unbounded Mind, Oxford University Press, 1993.

Metcalfe M[2003], Eleven Ways to Critique an Article, Vol. 23, No 2, University Of South Australia

Mitzell, A. 2010, August 9. Does terrorism help Gülen's Muslim missionaries? A first class revolution from the bottom up. Retrieved Feb 25, 2013, from Kurdish Media: htpp://www.kurdishmedia.com

Mitzell, A. 2008. The Rise of a New Ottoman Empire: The Trap of Interfaith Dialogue. Retrieved March 5, 2013, from Kurdish Aspects: http://kurdishaspects.com

Rodgers, G. 2010. "Fethullah Gulen: Infiltrating the U.S. Through Our Charter Schools?" Retrieved Feb 15, 2013, from Act for America: htpp://actforamerica.org

Rubin, M. 2010. "Fethullah Gulen Speaks." National Review Online.

Rubin, M. 2008. Turkey's Turning Point. National Review Online.

Schwartz, S. 2010. March 29. "Islamist Gülen Movement Runs U.S. Charter Schools." Retrieved Feb 12, 2013, from Islamist Watch: htpp://islamist-watch.org

Sharon-Krespin, R. 2009. "Fethullah Gülen's Grand Ambition: Turkey's Islamist Danger". Middle East Forum.

Stenhouse, P. 2007. "Islam's Trojan Horse? Turkish Nationalism and the Nakshibendi Sufi Order". Quadrant. Today's Zaman. 2009. Ergenekon File. Today's Zaman

Topuz, B. 2011. December 05, Historical Development of Azeri Education System and the Effects of the Private Azerbaijani-Turkish Schools, in Journal of Educational and Social Research Vol 1 No 5.

Türker, A. 2009. November 19. "Hypocrisy in languages: criticizing Fethullah Gülen, English or Turkish?" Today's Zaman.

WACH, J. Sociology of Religion, 1995, İstanbul.

Williams, P. 2010. "Exclusive: Has the Universal Caliphate Emerged from Pennsylvania? Is the CIA Serving the Needs of an Islamist? (Part Two)". Retrieved April 12, 2013. From thelastcrusade.org: http://www.thelastcrusade.org

Williams, P. 2010. April 9. "Exclusive: Obama Administration turns Blind Eye to Muslim Foreign Militia in Pennsylvania." Retrieved Feb 19, 2013, from Family Security Matters: htpp://www.familysecuritymatters.org

Williams, P. 2010. April 6. "Fethullah Gulen: Working for the Islamic Caliphate from Saylorsburg, PA". Retrieved Feb 8, 2013, from sheikyermami: http://www.sheikyermami.com

Williams, P. 2010. May 7. "Pennsysilvania Perfect Staging Area For next 9111" Retrieved March 22, 2013, from The Last Crusade: htpp://www.thelastcrusade.com

Yıldırım, E. (2003). 'Sosyolojik pozitivizm ve teoloji arasinda müphemleşen din sosyolojisi'. Journal of Social Science of D.P.Ü., vol. 9, p. $199-209$ 